\title{
Spirulina platensis: process optimization to obtain biomass
}

\author{
Spirulina platensis: otimização de processo para a obtenção de biomassa
}

\author{
Iracema de Oliveira MORAES ${ }^{1}$, Regina de Oliveira Moraes ARRUDA ${ }^{1,2 *}$, \\ Natália Rocha MARESCA ${ }^{3}$, Aline de Oliveira ANTUNES 3 , Rodrigo de Oliveira MORAES ${ }^{1,4}$
}

\begin{abstract}
Spirulina platensis is a photoautotrophic mesophilic cyanobacterium. Its main sources of nutrients are nitrate, urea, and ammonium salts. Spirulina cultivation requires temperature, light intensity, and nutrient content control. This microalgae has been studied and used commercially due to its therapeutic and antioxidant potential. In addition, several studies have reported its ability to use $\mathrm{CO}_{2}$, its immune activity, and use as an adjuvant nutritive factor in the treatment of obesity. The objective of this study is the production of biomass of $S$. platensis using different rates of stirring, nitrogen source, amount of micronutrients, and luminosity. A $2^{4}$ experimental design with the following factors: stirring (120 and $140 \mathrm{RPM})$, amount of nitrogen (1.5 and $2.5 \mathrm{~g} / \mathrm{L})$, amount of micronutrients $(0,25$ and $0,75 \mathrm{~mL} / \mathrm{L})(11$ and $15 \mathrm{~W})$, and luminosity was used. Fermentation was performed in a $500 \mathrm{~mL}$ conical flask with $250 \mathrm{~mL}$ of culture medium and $10 \%$ inoculum in an incubator with controlled stirring and luminosity. Fermentation was monitored using a spectrophotometer ( $560 \mathrm{~nm})$, and each fermentation lasted 15 days. Of the parameters studied, luminosity is the one with the highest significance, followed by the amount of nitrogen and the interaction between stirring and micronutrients. Maximum production of biomass for 15 days was $2.70 \mathrm{~g} / \mathrm{L}$ under the following conditions: luminosity $15 \mathrm{~W}$; stirring, $120 \mathrm{RPM}$; source of nitrogen, $1.5 \mathrm{~g} / \mathrm{L}$; and micronutrients, $0.75 \mathrm{~mL} / \mathrm{L}$.

Keywords: Spirulina platensis; human food; biomass; cyanobacteria.
\end{abstract}

\section{Resumo}

A Spirulina platensis é uma cianobactéria mesofílica, fotoautotrófica, que utiliza como nutrientes os nitratos, ureia e sais de amônio. O cultivo necessita de controle de temperatura, intensidade de luz e do teor de nutrientes utilizados. Esta microalga tem sido estuda pelo seu potencial nutricional, antioxidante, terapêutico e adjuvante em tratamento de obesidade. O objetivo deste trabalho foi a produção de biomassa de S. platensis em diferentes níveis de agitação, fonte de nitrogênio, quantidade de micronutrientes e luminosidade. No estudo desenvolvido na Universidade Guarulhos, foi realizado um planejamento experimental 24 com os parâmetros: agitação, fonte de nitrogênio, quantidade de micronutrientes e luminosidade. A fermentação foi feita em erlenmeyer de $500 \mathrm{~mL}$, com $200 \mathrm{~mL}$ de meio de cultura, e $10 \%$ de inóculo, em estufa com agitação e luminosidade controlada, por 15 dias e o acompanhamento realizado através de leitura em espectrofotômetro $(560 \mathrm{~nm})$. Dos parâmetros estudados o que apresentou maior significância foi a luminosidade, seguida da quantidade de fonte de nitrogênio e a interação agitação e micronutrientes. A produção máxima em biomassa por 15 dias foi de 3, 24 g/L nas condições de luminosidade 15 W, agitação em 120 RPM, fonte de nitrogênio $1,5 \mathrm{~g} / \mathrm{L}$ e micronutrientes em 0,75 mL/L.

Palavras-chave: Spirulina platensis; alimento; biomassa; cianobactéria.

\section{Introduction}

The blue-green algae are perhaps the oldest and most primitive forms of life on Earth. Fossilized microorganisms dating 3.5 billion years have been found. Algae have been used as human food since ancient times in various parts of the world such as China, India, Mexico, North America, Peru, Japan, and others.

The great nutritional interest for the production of algal biomass is due to its high protein content (60 to $65 \%$ in biomass of Spirulina sp.), high digestibility, and balanced content of some essential amino acids. Obtaining biomass of Spirulina sp. can be a representative example of algal production. Some production strategies include the use of fed batch type process (for controlling nutrient) and simple batch process. Spirulina platensis is an African species which develops in middle high temperatures $\left(25-26^{\circ} \mathrm{C}\right)$, alkaline $\mathrm{pH}$ (9.5 to 11 ), and high salt concentrations ranging from 8.5 to $200 \mathrm{~g} / \mathrm{L}$; therefore, their production is relatively simple and does not require a complex culture medium and high cost, thus enabling carrying out the present study (ARRUDA et al., 2009; PELIZER et al., 2002; PELIZER; MORAES, 2009).

Arthrospira (Spirulina) sp., is a filamentous cyanobacterium, autotroph, also known as blue-green algae, which owes its name to the nature of its helical or spiral filaments. This microorganism grows naturally in many places, particularly in shallow water

'Pesquisa e Desenvolvimento Experimental em Ciências Físicas e Naturais Ltda - PROBIOM TECNOLOGIA, Rua Latino Coelho, 1301, Prédio S, Parque Taquaral, CEP 13087-012, Campinas, SP, Brasil

2 Laboratório de Farmácia, Universidade Guarulhos - UnG, Praça Tereza Cristina, 88, Centro, CEP 07023-070, Guarulhos, SP, Brasil, e-mail: rarruda@prof.ung.br

${ }^{3}$ Laboratório de Farmácia, Programa UnG PIBIC-CNPq, Universidade Guarulhos - Un G, Praça Tereza Cristina, 88, Centro, CEP 07023-070, Guarulhos, SP, Brasil

${ }^{4}$ Departamento de Engenharia de Alimentos, Faculdade de Jaguariúna - FAJ, Rua Amazonas, 504, Jardim Dom Bosco, CEP 13820-000, Jaguariúna, SP, Brasil

${ }^{*}$ Corresponding author 
bodies and in the presence of sodium bicarbonate, an alkaline medium of high salinity (VONSHAK; TOMASELLI, 2000).

Some microalgae such as Spirulina and Chlorella are certified GRAS (Generally Recognized As Safe) and can be used as food without offering health risk. Since June $23^{\text {rd }}, 1981$, Spirulina has been legally approved by the FDA (Food and Drug Administration), which confirmed that

Spirulina is a source of protein and contains several vitamins and minerals. Spirulina can be legally marketed in the United States as a food as long as it is labeled accurately and contains no contaminated or adulterated substances (FOX, 1996, p. 89).

The cyanobacterium Spirulina has been marketed and studied because of its nutritional and therapeutic properties for the treatment of diseases such as cancer, hypercholesterolemia, and atherosclerosis. Certain compounds present in Spirulina, such as phenolic compounds, phycocyanin, and tocopherol may have antioxidant activity (COLLA; FURLONG; COSTA, 2007; MULITERNO et al., 2005; ANDRADE; CAMERINI; COSTA, 2008).

Nutritional studies show that these microorganisms have one of the highest protein contents ever found, high nutritional value, good digestibility, and all essential amino acids in the proportions recommended by FAO, with the exception of methionine. (AVILA-LEON et al., 2010). Some technical aspects of Spirulina production have advantages over those of other of photoautotrophs, such as its easy harvest from the culture medium due to its spiral shape and larger size (diameter of $10 \mu \mathrm{m}$ and length of tens to hundreds of $\mu \mathrm{m}$ ). The biomass production can vary according to the culture medium used and the conditions of the external environment. The manipulation of culture conditions can promote the biosynthesis of various compounds, and in addition, one can control these variables in order to reduce the costs of the production process (REINEHR, 2001).

Avila-Leon et al. (2012) investigated the production of single-cell proteins from Arthrospira platensis due to its biomass composition and ability to grow in alternative media. They evaluated the effects of different dilution rates $(D)$ and urea concentrations $\left(N_{0}\right)$ on $A$. platensis continuous culture in terms of growth, kinetic parameters, biomass composition, and nitrogen removal.

The dependence of cell growth as a function of light intensity has been observed, i.e. there is a correlation between the increase of luminous energy received and cell growth, although limited by certain enzymes produced during growth (PELIZER et al., 2002). This boundary is called light saturation point, which is 5-10 Klux for cyanobacteria (BALLONI et al., 1980). This experimental finding indicates that the maximum cell growth rate is limited by other processes besides the assimilation of carbon and nitrogen.

Since Spirulina sp. is autotrophic, light intensity causes the metabolites to vary its biomass according to the incidence of light, ie higher production under higher light intensities with shorter feed (BEZERRA, 2006).
Arruda et al. (2009) states that under the conditions studied, the one that yielded better results in terms of biomass production in all trials was the bioreactor containing $300 \mathrm{~mL}$ of culture medium Paoletti et al. modified with half of the nitrogen source $\left(\mathrm{KNO}_{3}\right)$. Working with the viability of the production of Spirulina platensis in a plastic reactor (polypropylene with $1 \mathrm{~L}$ volume), the best results in terms of biomass production was achieved in the treatment with $300 \mathrm{~mL}$ of medium and $15 \%$ of inoculum with an average yield of $2.32 \mathrm{~g} / \mathrm{L}$ in 18 days of fermentation.

Arruda et al. (2009) investigated the viability of the production process of Spirulina platensis in a plastic reactor (polypropylene with $1 \mathrm{~L}$ volume) facilitating its transport and reducing the cost of production. The best results for the production of biomass found were with $300 \mathrm{~mL}$ volume of culture medium and $15 \%$ of inoculum with an average yield of $2.32 \mathrm{~g} / \mathrm{L}$ in 18 days of fermentation.

Pelizer et al. (2008), determined the total protein content by the micro-Kjeldahl method and obtained an average of $49 \%$.

Under the conditions examined, the one which yielded better results in terms of biomass production in all trials was the bioreactor containing $300 \mathrm{~mL}$ of culture medium modified with half of the nitrogen source $\left(\mathrm{KNO}_{3}\right)$. S. platensis was grown in an autotrophic culture medium with sodium bicarbonate and mixotrophic with $0.25,0.50,0.75$, and $1.00 \mathrm{~g} / \mathrm{L}$ of dried molasses (MEP) or liquid molasses (MEL); the growth was completed in 35 days. Maximum biomass concentration $(2.83 \mathrm{~g} / \mathrm{L})$ and a yield of $0.098 \mathrm{~g} / \mathrm{L}$ day were reaches in cultures with MEL $0.50 \mathrm{~g} / \mathrm{L}$. Cultures with MEP $0.25 \mathrm{~g} / \mathrm{L}$ reached biomass concentration of $2.59 \mathrm{~g} / \mathrm{L}$ and productivity of $0.066 \mathrm{~g} / \mathrm{L}$.day. It can be concluded that molasses can be used to obtain biomass of algae to help combat malnutrition (ANDRADE; COSTA 2008).

The cultivation of S. platensis with the addition of glucose was also studied. A $2^{3}$ factorial design was used for the cultivation, and the variables were: the concentration of glucose $(0.5 \mathrm{~g} / \mathrm{L}$ and $1.0 \mathrm{~g} / \mathrm{L})$, the dilution of Zarrouk medium (50\% and $75 \%$ ), and illumination (1800 lux and 3000 lux). The maximum concentration achieved was $5.38 \mathrm{~g} / \mathrm{L}$ with a growth rate of $0.0063 \mathrm{~h}^{-1}$ and $0.5 \mathrm{~g} / \mathrm{L}$ glucose, medium dilution of $75 \%$, and illuminance of 3000 lux (MULITERNO et al., 2005).

The present study investigated the production of biomass of $S$. platensis under different rates of stirring, nitrogen source concentration, amount of micronutrients, and luminosity, as well as the influence of these culture medium factors on the production of Spirulina platensis focusing on biomass increase under different rates of stirring, nitrogen source, amount of micronutrients, and luminosity.

\section{Materials and methods}

The factors considered in this experiment were stirring, light, nitrogen content, and amount of micronutrients. Fermentation was performed in a $500 \mathrm{~mL}$ conical flask with $250 \mathrm{~mL}$ of culture medium and $10 \%$ inoculum in an incubator with controlled stirring and light. Fermentation monitoring was carried out using a spectrophotometer $(560 \mathrm{~nm})$, and each fermentation lasted 15 days. A $2^{3}$ experimental design was used, and the values of each parameter studied are shown in Table 1. 
All experiments were performed in duplicate. The variation in these values was used to verify the effect of the factors on the production of bioproducts.

The medium used for the fermentation is shown in Table 2. Experiments were performed in duplicate using $500 \mathrm{~mL}$ of each culture medium.

Table 1. Values assigned to each parameter studied for the production of $S$ platensis.

\begin{tabular}{lcc}
\hline \multirow{2}{*}{ Parameters } & \multicolumn{2}{c}{ Values } \\
\cline { 2 - 3 } \multicolumn{1}{c}{ Stirring } & + & - \\
Light & $140 \mathrm{rpm}$ & $120 \mathrm{rpm}$ \\
Nitrogen & $15 \mathrm{~W}$ & $11 \mathrm{~W}$ \\
Micronutrients & $2.5 \mathrm{~g} / \mathrm{L}$ & $1.5 \mathrm{~g} / \mathrm{L}$ \\
& $0.75 \mathrm{~mL} / \mathrm{L}$ & $0.25 \mathrm{~mL} / \mathrm{L}$ \\
\hline
\end{tabular}

Table 2. Composition of mineral medium (assuming a volume of $500 \mathrm{~mL}$ )

\begin{tabular}{lllll}
\hline & \multicolumn{1}{c}{++} & \multicolumn{1}{c}{+-+} & -- \\
\hline $\mathrm{NaCl}$ & $0.46 \mathrm{mg}$ & $0.46 \mathrm{mg}$ & $0.46 \mathrm{mg}$ & $0.46 \mathrm{mg}$ \\
$\mathrm{Na}_{2} \mathrm{SO}_{4}$ & $0.94 \mathrm{mg}$ & $0.94 \mathrm{mg}$ & $0.94 \mathrm{mg}$ & $0.94 \mathrm{mg}$ \\
$\mathrm{K}_{2} \mathrm{HPO}_{4}$ & $0.25 \mathrm{mg}$ & $0.25 \mathrm{mg}$ & $0.25 \mathrm{mg}$ & $0.25 \mathrm{mg}$ \\
$\mathrm{Na}_{2} \mathrm{CO}_{3}$ & $4.45 \mathrm{mg}$ & $4.45 \mathrm{mg}$ & $4.45 \mathrm{mg}$ & $4.45 \mathrm{mg}$ \\
$\mathrm{NaHCO}_{3}$ & $7.58 \mathrm{mg}$ & $7.58 \mathrm{mg}$ & $7.58 \mathrm{mg}$ & $7.58 \mathrm{mg}$ \\
$\mathrm{CaCl}_{2} 2 \mathrm{H}_{2} \mathrm{O}$ & $0.025 \mathrm{mg}$ & $0.025 \mathrm{mg}$ & $0.025 \mathrm{mg}$ & $0.025 \mathrm{mg}$ \\
$\mathrm{KNO}_{3}$ & $1.25 \mathrm{mg}$ & $1.25 \mathrm{mg}$ & $0.75 \mathrm{mg}$ & $0.75 \mathrm{mg}$ \\
$\mathrm{MgSO}_{4}$ & $0.13 \mathrm{mg}$ & $0.13 \mathrm{mg}$ & $0.13 \mathrm{mg}$ & $0.13 \mathrm{mg}$ \\
EDTA solution & $0.5 \mathrm{~mL}$ & $0.5 \mathrm{~mL}$ & $0.5 \mathrm{~mL}$ & $0.5 \mathrm{~mL}$ \\
Micronutrients & $0.40 \mathrm{~mL}$ & $0.20 \mathrm{~mL}$ & $0.40 \mathrm{~mL}$ & $0.20 \mathrm{~mL}$ \\
\hline & & & &
\end{tabular}

\section{Results and discussion}

The response of the experimental design was achieved by the absorbance read at the end of the experiment, which was converted into biomass ( $\mathrm{g} / \mathrm{L}$ ) by curve fitting. (Equation 1 ). These results are shown in Table 3 and Figure 1. Since the experiments were performed in duplicate, the average of the values of each experiment was used.

Biomass $=($ absorbance reading $) * 1.0955+0.506$

Table 3. Production of $S$. platensis under different conditions of agitation, light, amount of nitrogen and micronutrient.

\begin{tabular}{ccccccc}
\hline \multirow{2}{*}{ Assay } & \multicolumn{5}{c}{ Experimental design } & Biomass \\
\cline { 2 - 5 } & Stirring & Light & Nitrogen & Micronutrients & $(\mathrm{g} / \mathrm{L})$ \\
\hline 1 & + & + & + & + & 2.3705 \\
2 & + & + & + & - & 2.5738 \\
3 & + & + & - & + & 2.2194 \\
4 & + & + & - & - & 2.3530 \\
5 & + & - & + & + & 1.1397 \\
6 & + & - & + & - & 1.3085 \\
7 & + & - & - & + & 1.1797 \\
8 & + & - & - & - & 1.3085 \\
9 & - & + & + & + & 2.4631 \\
10 & - & + & + & - & 2.5524 \\
11 & - & + & - & + & 2.7003 \\
12 & - & + & - & - & 1.9838 \\
13 & - & - & + & + & 1.2493 \\
14 & - & - & + & - & 1.2641 \\
15 & - & - & - & + & 1.0554 \\
16 & - & - & - & - & 0.9825 \\
\hline
\end{tabular}

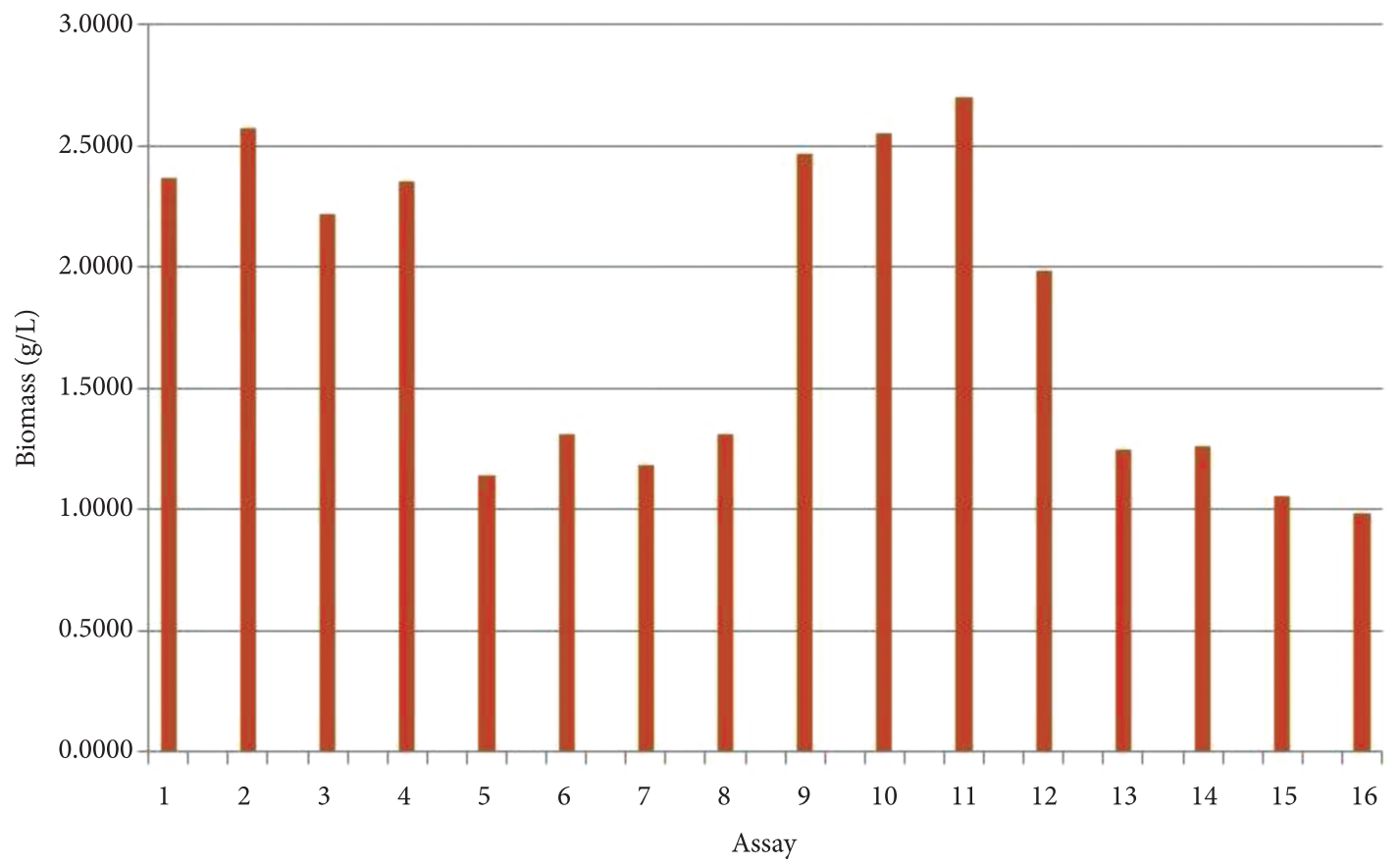

Figure 1. Production of S. platensis varying stirring, light, amount of nitrogen, and micronutrients. 
The experimental results summarized in Table 3 were analyzed using the following software programs: Essential Regression (ER) and Essential Experimental Design (EED) for Excel 97/2000/2002/2003 (http://www.jowerner.homepage.tonline.de/download.htm) for effect estimation, as shown in Table 4.

The following figures show the production trends. Figure 2 shows that production increased with increased amount of light and nitrogen source. Figure 3 shows that for production increase, stirring rate and micronutrients should have opposite values, i.e., if stirring rate is increased, less amount of micronutrients should be used; and with decreased stirring rate, greater amount of nutrients should be used.

The results found are similar to those found by Muliterno et al. (2005); the maximum cellular concentration of 5.38 g.L. $\mathrm{L}^{-1}$ and maximum specific growth rate of $0.0063 \mathrm{~h}^{-1}$ were obtained with a glucose concentration of 0.5 g.L. $\mathrm{L}^{-1}, 50 \%$ dilution, and 1800 lux of illuminance.

Andrade and Costa (2008) found maximum biomass concentration of $2.83 \mathrm{~g} . \mathrm{L}^{-1}$ and productivity of $0.098 \mathrm{~g} . \mathrm{L}^{-1}$. day ${ }^{-1}$, and these results were reached in cultures with MEL (liquid molasses) of 0.50 g.L. $\mathrm{L}^{-1}$.

Kornfeld et al. (2003), introduced a new culture medium for the production of Spirulina platensis biomass based on an alkaline solution from citrus industry effluent supplemented with sources of nitrogen, phosphorus, and potassium, which had an absorbance of 1024 and is equivalent to $5.1 \mathrm{~g} \cdot \mathrm{mL}^{-1}$ in a 5 day experiment.

The use of half of micronutrient concentration showed that biomass and absorbance values were lower when compared with those found by Andrade and Costa (2008) and Kornfeld et al. (2003), but the culture medium of these experiments were supplemented with more expensive nutrient sources.

Lacaz-Ruiz (2003) conducted an experiment to evaluate the biomass production of Spirulina platensis in Lacaz-Ruiz media prepared with ash and Eucalyptus spp. in Paoletti culture medium.

Both media were prepared using the same following culture conditions: amount of inoculum $(75 \mathrm{~mL})$, light intensity, reading at a wavelength of $560 \mathrm{~nm}$, agitation, and temperature $\left(33.0 \pm 1.0^{\circ} \mathrm{C}\right)$. The results of the initial and the final absorbance for the Paoletti culture medium were 0447 and 1037, respectively, and for the Lacaz-Ruiz culture medium they were 0329 and 0831 , respectively, during 6 days of experiment.

Spirulina platensis cultivated for 23 days under controlled temperature $\left(30^{\circ} \mathrm{C}\right)$ and light intensity in three different media: Paoletti medium (control), Paoletti medium supplemented with 1 g. $\mathrm{L}^{-1} \mathrm{NaCl}$ (saline water), and medium prepared according to Paoletti culture medium with desalinator effluent; the cellular concentrations results were: $2.587,3.545$, and 4.954 g. $\mathrm{L}^{-1}$ respectivelly, similar to those found by Volkman et al. (2008).

Table 4. Influence of each factor studied on the results obtained by experimental design.

\begin{tabular}{|c|c|c|c|c|c|c|c|}
\hline \multicolumn{8}{|c|}{ Biomass $=\mathrm{b} 0+\mathrm{b} 1^{\star} \mathrm{L}+\mathrm{b} 2^{\star} \mathrm{N}+\mathrm{b} 3^{\star} \mathrm{A}^{\star} \mathrm{M}$} \\
\hline & & $\mathrm{P}$ value & Error & $-80 \%$ & $80 \%$ & t Stat & VIF \\
\hline b0 & 1.794 & $5.29728 \mathrm{E}^{-25}$ & 0.04980 & 1.729 & 1.859 & 36.03 & b1 \\
\hline b1 & 0.608 & $9.87966 \mathrm{E}^{-13}$ & 0.04980 & 0.543 & 0.673 & 12.21 & 1.000 \\
\hline $\mathrm{b} 2$ & 0.07117 & 0.164 & 0.04980 & 0.00581 & 0.137 & 1.429 & 1.000 \\
\hline b3 & -0.08247 & 0.109 & 0.04980 & -0.148 & -0.01711 & -1.656 & 1.000 \\
\hline
\end{tabular}

Where: $\mathrm{L}=$ light, $\mathrm{N}=$ nitrogen content, $\mathrm{A}=$ stirring and $\mathrm{M}=$ amount of micronutrients.

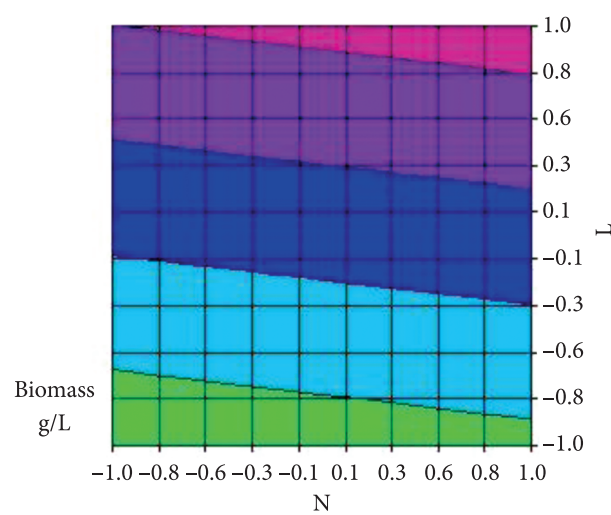

Figure 2. Interaction between the factors light (L) and quantity of nitrogen $(\mathrm{N})$ for the production of $S$ platensis biomass.

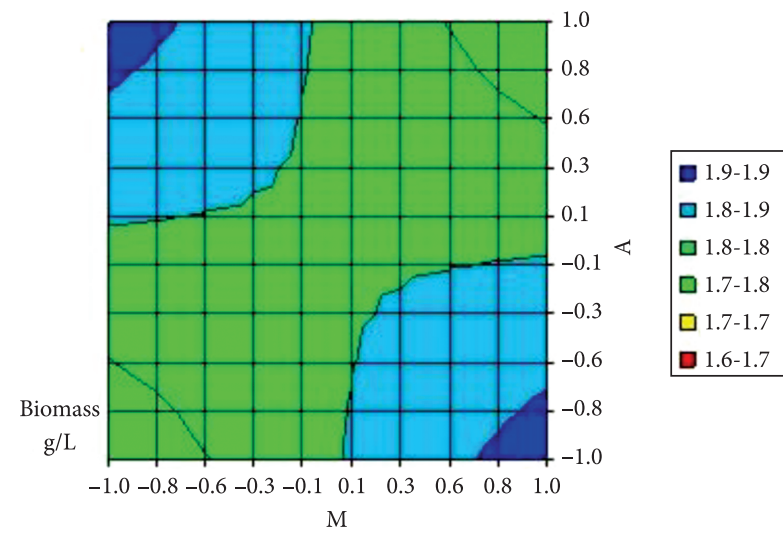

Figure 3. Interaction between the factors stirring (A) and amount of micronutrients $(\mathrm{M})$ for the production of $S$ platensis biomass. 


\section{Conclusion}

Light intensity and nitrogen source had greater influence on the production of Spirulina platensis.

The increase in light intensity favored the production of biomass, and this was the factor that most influenced the present study.

When $2.5 \mathrm{~g} / \mathrm{L}$ of Nitrogen instead of $1.5 \mathrm{~g} / \mathrm{L}$ was used, there was an increase in biomass.

Stirring rate and amount of micronutrients had no influence on the biomass in the conditions studied, but the interaction between these factors had an antagonistic effect.

\section{Acknowledgements}

The authors are grateful to $\mathrm{CNPq}$ - for the Fellowship Programme for Scientific Initiation (PIBIC) and to Universidade Guarulhos.

\section{References}

ANDRADE, M. R.; COSTA, J. A. V. Cultivo da microalga spirulina platensis em fontes alternativas de nutrientes. Ciência e Agrotecnologia, v. 32, n. 5, p. 1551-1556, 2008. http://dx.doi. org/10.1590/S1413-70542008000500029

ANDRADE, M. R.; CAMERINI, F. V.; COSTA, J. A. V. Perda química de carbono e cinética do crescimento celular em cultivos de Spirulina. Química Nova, v. 31, n. 8, p. 2031-2034, 2008. http:// dx.doi.org/10.1590/S0100-40422008000800022

ARRUDA, R. O. M. et al. Fermentação de Spirulina platensis sob condições naturais de temperatura e insolação. Revista da Saúde, v. 3, n. 3, p. 16-19, 2009.

AVILA-LEON, I. A. et al. Estudo do cultivo de Spirulina platensis por processo contínuo com uréia como fonte de nitrogênio. $2010.99 \mathrm{f}$. Dissertação (Mestrado em Tecnologia Bioquímico-Farmacêutica)Universidade de São Paulo, São Paulo, 2010.

AVILA-LEON, I. A. et al. Arthrospira platensis biomass with high protein content cultivated in continuous process using urea as nitrogen source. Journal of Applied Microbiology, v. 6, p. 1086-1094, 2012.

BALLONI, W. et al. Biologia fondamentale del genere Spirulina. In: MATERASSI, R. (Ed.). Prosoettive della Coltura di Spirulina in Italia. Firenze, 1980.
BEZERRA, R. P. Influência do Tempo de alimentação e da intensidade luminosa no cultivo de Spirulina platensis sob alimentação de cloreto de amônio. 2006. 153 f. Dissertação (Mestrado em Tecnologia Bioquímico-Farmacêutica)-Universidade de São Paulo, São Paulo, 2006.

COLLA, L. M.; FURLONG, E.; COSTA, J. A. V. Antioxidant properties of Spirulina (Arthospira) platensis cultivated under different temperatures and nitrogen regimes. Brazilian Archives of Biology and Technology, v. 50, n. 1, p. 161-167, 2007. http://dx.doi. org/10.1590/S1516-89132007000100020

FOX, R. D. Spirulina production \& potencial. Aix-en- Provence: Edisud, 1996. p. 89.

KORNFELD, M. E. et al. Utilização de efluente da indústria cítica (água amarela) na produção de Spirulina platensis. In: LACAZ-RUIZ, R. Espirulina: estudos e trabalhos. São Paulo: Roca, 2003. p. 107-18.

LACAZ-RUIZ, R. (Coord.). Espirulina: estudos e trabalhos. São Paulo: Rocca, 2003. 296 p.

MUliTERNO, A. et al. Cultivo mixotrófico da microalga Spirulina platensis em batelada alimentada. Ciência e Agrotecnologia, v. 29 , n. 6, p. 1132-1138, 2005. http://dx.doi.org/10.1590/S141370542005000600005

PELIZER, L. H. et al. Influence of inoculum age and concentration in Spirulina platensis cultivation. Journal of Food Engineering, v. 56, p. 371-375, 2002. http://dx.doi.org/10.1016/S0260-8774(02)00209-1

PELIZER, L. H.; MORAES, I. O. Development of solid state cultivation process for Spirulina platensis production. New Biotechnology, v. 25, p. 223-224, 2009. http://dx.doi.org/10.1016/j.nbt.2009.06.189

PELIZER, L.H. et al. Protein, chlorophyll and lipid production during Spirulina platensis cultivation for food and feed use. In: THANGADURAI, W. et al. Biotechnology for Food, Environment and Agriculture. Agrobios, India, 2008. chapt. 4.

REINEHR, C. O. Estudo do cultivo semicontínuo de microalga Spirulina platensis utilizandoágua da lagoa Mangueira. 2001. $132 \mathrm{f}$. Dissertação (Mestrado em Ciência e Engenharia de Alimentos)Universidade Federal do Rio Grande, Rio Grande, 2001.

VOLKMAN, H. et al. Cultivo de Arthrospira (Spirulina) platensis em rejeito de desalinizador e meio sintético dessalinizado: teor de proteínas e aminoácidos. Brazilian Journal of Microbiology, v. 39, n. 1, p. 98-101, 2008. http://dx.doi.org/10.1590/S151783822008000100022

VONSHAK, A.; TOMASELLI, L . Arthrospira (Spirulina): systematics and ecophysiology. In: WHITTON, B. A.; POTTS, M. (Eds.). Ecology of Cyanobacteria. Kluwer Academic Publishing, 2000. p. 505-523. 